\title{
DEVELOPING CURRICULA FOR ENGLISH FOR OCCUPATIONAL PURPOSES: A CASE STUDY AT A SOUTH AFRICAN UNIVERSITY OF TECHNOLOGY
}

\author{
E. Rautenbach* \\ e-mail: RautenbachE@tut.ac.za \\ C. C. Mann* \\ e-mail: ccpmann@yahoo.com
}

\section{L. van Ryneveld}

Faculty of Veterinary Science

University of Pretoria

Pretoria, South Africa

e-mail: linda.vanryneveld@up.ac.za

*Department of Applied Languages

Tshwane University of Technology

Pretoria, South Africa

\section{ABSTRACT}

The demand for English for Occupational Purposes (EOP) is growing proportionally to the universal demand for employees, who can function in the lingua franca, English, in their fields of specialisation. Therefore, the training of students at universities of technology, which aim to produce graduates who can perform successfully upon entry into the occupational world, should include the teaching and learning of EOP. This study set out to determine how best to develop EOP curricula, using wants and needs analyses, including all stakeholders at a university of technology, and adopting a case study approach. There was particular focus on: the students, since EOP is learner-centred; the authenticity of learning materials per field of specialisation; and, collaboration between language services-rendering and language services-requesting departments. The main conclusions drawn were that English proficiency plays a central role in the success of learning EOP, and direct feedback from industry on student wants and needs emerged as essential in curriculum planning.

Keywords: English for Occupational Purposes, wants and needs analysis, curriculum development, university of technology

\section{INTRODUCTION}

Teaching in a Department of Applied Languages (APL) at a university of technology for the 
past nineteen years, we had never come across an existing set of principles and procedures for the curriculum development of English for Specific Purposes (ESP) at the institution. Policy dictates that, as the service-rendering department, APL render services to all departments across the university, offering subjects related to the English language, or Communication skills.

Although the Department is situated at a university of technology (UoT), with the assumption that the specific wants and needs of the various industries in which students would be employed should be taken into account, this is not currently the case. A set of principles and procedures for the development of curricula, specifically for those to whom the subjects in English and/or Communication Skills are offered, could bring the offerings in line with the global landscape.

Stakeholders to be considered in the determination of content for English service subjects are the client departments to whom services are rendered. Until recently, it had not been common practice for APL lecturers to be invited to service-requesting department planning meetings. From the meetings attended in the past few years, it has emerged that these client departments, led by their Advisory Board committees, expect English for Occupational Purposes (EOP) to be taught. On the other hand, during reviews conducted by the University's Directorate for Quality Promotion over time, it emerged that they preferred English for Academic Purposes (EAP) to be taught. The dichotomy created by the wants/needs of different stakeholders relates directly to the fact that a proper needs analysis had not yet been undertaken, with regard to the English taught by the APL services section.

The perceptions of students registered for English and/or Communication Skills also influenced the proposed review of the curricula of these subjects. Experience with these students had shown that students did not grasp the importance of the subjects for their capability to perform well in industry. It was also evident that the face validity that students attached to English, as a subject, could influence their performances in English, and their content subjects.

\section{ESP/EOP: BACKGROUND, CONCEPTS, AND PROGRAMME CHARACTERISTICS}

\section{Brief history and concepts}

English for Specific Purposes (ESP) is English used in specific occupational or professional settings; in other words, it is English usage determined by the language wants and needs of the learners, for specific purposes, in accordance with their professions, or job descriptions (Esimaje 2012, 24). 
The end of the World War II, and the oil crisis of the 1970s - when scientific and economic activities were on the rise, witnessed a rise in the need for ESP, as English assumed the role of world language (Hutchinson and Waters 1987, 6). This meant that ESP curriculum design had to take into account the demands of different stakeholders in the world of commerce, for example. ESP has grown especially rapidly in Japan, and in south-east Asia, and is also required increasingly today in industry in South Africa.

ESP is regarded as an overarching term for English for Academic Purposes (EAP), and English for Occupational Purposes (EOP). EAP is English that is taught to prepare students to be academically proficient, while EOP is English aimed specifically at enabling the student's English proficiency and skills to function in their various fields of specialisation in the occupational world. According to Ahmadi and Bajelani (2012, 795), students require English proficiency at a certain level to be able to study EOP successfully. At a university of technology, where students are trained to function immediately upon entry into the occupational world directly after graduation, EOP would be essential.

In order to improve the implementation of ESP in a specific environment, one should consider what is regarded as seminal in this field. Swales (1990, in Salmani-Nodoushan 2002, 8) mentions five “enduring” conceptions as the underlying, essential principles of ESP:

- $\quad$ authenticity - the use of authentic materials to learn ESP (based on the real-life field of specialisation of learners in their chosen occupation);

- $\quad$ research base - the register analysis of corpus, in terms of texts utilised in the learners' chosen field of occupation and specialisation;

- $\quad$ language/text - register considered, in terms of lexicon and grammar, instead of discourse analysed for the purposes of communication;

- $\quad$ learning needs - needs determined by means of needs analysis for the learners' field of specialisation, or occupation;

- learning methodology - this should be chosen, based on the fact that ESP is learnercentred.

One of the characteristics of EOP, like ESP, is that it is learner-centred (Hutchinson and Waters 1987, 19), i.e., learner wants and needs are taken into consideration in developing the curriculum (of English as a subject) (see also Gatehouse 2001, 7). Therefore, it is essential to ensure that an ESP curriculum is not based on mere perceptions and intuitions, but on a proper EOP needs analysis. Belcher $(2004,166)$ suggests that, because ESP pedagogy is driven by 
needs analysis, unlike other more theory-based pedagogical approaches, its practitioners should gather "empirical needs assessment-data”, to make sure that learning materials meet the specific needs identified.

Gatehouse (2001, 7) also proposes that, aside from a proper needs analysis, it should be emphasised that: learners of EOP should learn to use the type of language required of a specific occupational context; they should equally learn more general academic skills (e.g., in conducting research, etc.), and General English (GE) in informal contexts, like social settings, to communicate effectively. In this way, the curriculum development and teaching of ESP/EOP would focus on the learners' particular needs, exposing them to field-specific terminology, as they learn to use English for academic purposes, and function with GE in general society.

Sifakis $(2003,206)$ supports the idea that the ability to function well within a specific occupation, with reference to EOP, is dependent on the learner's ability to execute specific professional tasks, and EOP syllabi should be planned on this basis. In similar vein, Hutchinson and Waters $(1987,8)$ had suggested that learners should be taught the English they need for what they need it specifically for.

According to Kim (2008, 76), data from interviews with employees of some Korean companies suggests that, in more recent times, the following characteristics of ESP/EOP have emerged:

i) There is a clear purpose (e.g., business skills for presentations in English, business letter writing, etc.);

ii) It addresses needs in proficiency, as revealed by a needs analysis, of workplace needs;

iii) It tantamounts to responding to, and satisfying, educational needs;

iv) The relevant vocabulary and expressions related to their workplace; and,

v) It is more suited to immediate needs, and serves more practical purposes than GE in the workplace.

Fatihi $(2003,39)$ describes needs analysis as a process employed to identify and facilitate the design of a suitable curriculum, with relevant teaching/learning and management objectives, so as to ensure learning in an environment that closely simulates real-life situations in which the learner should be able to perform roles in a specific setting (i.e., actual and relevant linguistic, lexical, and discoursal needs). Le Ha $(2005,7)$ suggests that wants should also be considered, in order to enable learners to master a language, but that learner needs are essential for learning a language. 
Songhori (2008, 20-21) is of the opinion that no one approach to needs analysis reliably proposes what is required to enhance learning, and that, currently, there is an understanding that different types of needs analyses complement one another, rather being exclusive, and that each of them offers a piece to unravel the jigsaw of needs analysis.

In order to look at best practice in conducting a wants and needs analysis, it would be important to consider the instruments used in such an analysis. Hutchinson and Waters (1987, 58) recommend that the following methods, and preferably "a good mix" of them, could be used to conduct a needs analysis: questionnaire; interview; observation; and, informal consultations.

ESP practitioners should also be conscious of the fact that needs analysis is a process that should be engaged in with careful regard for the perceptions of all the stakeholders involved. According to Benesch (1996, 724-736), needs analysis is a process that is both political and subjective, tied in to the unequal social standings of the different stakeholders, e.g., employers, academic institutions, teachers, and learners, and that this has an effect on the development of curricula - which should be kept in mind. She maintains that decision-making about change implemented in the situation of focus is determined by conditions on the ground, including the teachers' status, the responsiveness of content teachers, the political culture in the academic establishment, and the country (Benesch 1996, 726). This is true in most cases where new curricula are developed, and the role and place of ESP/EOP in these, considered. Oftentimes, there are ESP/EOP wants and needs per specific course, but realities, like the allocation of credits, could hamper these being fully addressed.

The differing perceptions of stakeholders, as discussed by Esteban and Vallejos Martos (2002, 11-12), in describing the collaboration between the ESP teacher and student as complicated, because they might not agree on target needs, should also be taken into account. The possibility remains that they probably do not regard deficiencies and learning needs in the same way. Smythe and Nikolai $(2002,166)$ provide further confirmation of this, when they state that, when the "communication concerns model" was applied to Accounting students, it showed that undergraduate students' main concern was about self; namely, the ability to express oneself. For graduate students, it was both a concern for tasks, e.g., the ability to design a good presentation, and self-concern; and, professional accountants had impact concerns, e.g., the ability to earn the respect of clients, task concerns, and self-concern - almost in equal measure.

ESP/EOP curriculum development should, inevitably, take into particular consideration matters of register (whether formal or informal), genre (regularities and patterns of structure, which distinguish one type of text from another; Songhori, 2008, 27), vocabulary/lexicon 
(specialised lexical knowledge regarded as of the utmost importance to learners' communicative competence; Diaz 2011, 1). Hutchinson and Waters $(1987,10)$ state that an ESP course should, therefore, give priority to these features.

Curriculum development should be understood here in the context of EOP. Rajaee, Abbaspour and Zare $(2012,2)$ observe that "syllabus" refers to a name or table of contents for a particular subject or class, and to design a syllabus means to decide what content should be included, and how this should be arranged, whereas “curriculum” refers to all the content and events the establishment schedules throughout the academic year to actualise learning and teaching. Nunan $(1987,75)$ proposes that assistance in developing a curriculum may include persons acting in a programme advisory role, and that such support cannot be ignored, or seen in isolation.

A university of technology (UoT) is understood here as an institution of higher learning offering career-focused education and training. Consequently, the role of the EOP curriculum developer is to facilitate the learner's capability to communicate successfully professionally in their work setting.

Based on the need for training learners who could emerge into the world of work, fully equipped to function in the lingua franca, English, the question arises: What is the importance of EOP in higher education? The need for ESP - and, under that umbrella, the need for EOP is growing daily. Despite on-going research done in this field, and daily new developments, the knowledge base for EOP is still lacking. Belcher $(2004,177)$ agrees that the research done on ESP so far is still inadequate:

“... [d]espite the research efforts of several generations of ESP specialists - including both action research and more formal published research, probably few in this field, as is the case throughout ELT, are satisfied with the current state of knowledge.”

Although the knowledge base for EOP is still regarded as lacking, Brunton $(2009,8)$ foresees the demand for specific courses inevitably increasing, given expanding globalisation, and the constant mobility of workers worldwide. As more countries and regions with economic prowess arise, e.g., China, India, Dubai, Malaysia, and Eastern Europe, the need for workers with proficiency in English for the workplace will grow.

This need for EOP implies a very real challenge to institutions of learning to provide wellresearched curriculum development for their English courses aimed at training in EOP. Popescu (2012, 4185) is of the opinion that ESP courses are of primary importance at technical universities, because the dynamics of today's development in all spheres of activity is becoming 
more complex day-by-day. She adds that, inevitably, communication holds the key to success or failure, and that courses in English (ESP, in particular), should be a compulsory subject in the curriculum for at least two years of study.

According to Kennedy (2012, 53), education across borders will continue to expand, and its development will challenge ESP and EAP over the next 20 years, especially EOP, which is being neglected. Therefore, further research in this field is of the essence, in order to support better practice in the design and implementation of ESP/EOP curricula.

\section{Characteristics of ESPIEOP programmes}

Ahmadi and Bajelani $(2012,792)$ observe that the current main purpose of ESP is to train students to read and understand content in English with little difficulty in their specific functions; however, only a few students understand the texts, and even fewer master ESP. They maintain that ensuring students comprehend special English is the most crucial and enduring goal of General English (GE) textbooks (2012, 793). Therefore, a certain English proficiency is required before students are able to master ESP content, since it does not address a lack thereof. Ngoepe $(2012,61)$ asserts that ESP materials assume some language proficiency in GE, and, therefore, concentrate straightway on areas of English specifically related to the topic being treated.

Carver (1983) argues that these different language levels, prior learning, and experience make the drafting of ESP courses and teaching very difficult, and, to resolve this, "minimum entrance standards" should be set for these areas, because students' limited English proficiencies simply find content activities impossible to master. This would have an effect on admission requirements for these courses, and should be considered when the level at which an ESP course is presented is decided on.

Also to be taken into account, regarding ESP/EOP programmes, would be authentic learning materials. Esteban and Vallejos Martos (2002, 10-11) assert that the content teacher should provide the topic which is the "carrier content", while the language teacher's role is to provide the linguistic dimension, which is the "real content".

Dovey (2006, 390-391) examines the distinction between EAP and EOP programmes, and concludes that, with the emphasis on knowledge, based on innovating, learning fast in constantly changing circumstances is one of the most desirable attributes of employees in the modern workplace, the most valued attribute being knowing how to learn, which is anchored in the crucial ability of communicating effectively with managers and colleagues. The author argues that the transferability of language skills from an academic to a professional setting is 
not often highlighted. The belief is that the purpose of disciplinary pedagogies, and of EAP, is the development of the student's knowledge and language proficiency, and while this might be the case of postgraduate research students, it is not so for the majority of postgraduate coursework students (Dovey 388). Therefore, EOP would not be seen as a vehicle to improve English proficiency per se.

Sujana $(2012,1)$ adds that the results of teaching English in non-English departments in most Indonesian universities leave much to be desired, since the English proficiency levels of most students' are very low. This is caused by disagreements about target needs, students' poor basic levels of English, their high expectations, the limited number of credits in English, high class sizes, and poor ESP teacher training (ibidem.). This is, unfortunately, the reality in most institutions where curriculum development of ESP/EOP is taking place. These problems are hampering the inclusion of ESP/EOP for the purpose of training students for occupational purposes.

According to Belcher (2004, 178), the ESP curricula of many practitioners are already deliverying good results, but ways of assessing ESP's current and future inputs to the development of individuals and communities remain undeveloped.

\section{ESP/EOP and English proficiency in South Africa}

If the requirements for teaching EOP successfully in South Africa were to be reviewed, the students' educational needs, and, specifically, the English proficiency required to learn EOP successfully, poses a challenge in the design of any curriculum for EOP.

According to Prince and Yeld (2012, 2), the Basic Education Department's report on the 2011 assessments in South Africa indicates that less than a third of all Grade 6 learners achieved anything near the competencies envisioned by the curriculum, and that this "dismal level of performance" is still evident in higher education, where the first year student drop-out rate is about 40 per cent, while only about 15 per cent complete their degree programmes in the minimum period. To bridge the gap between schools and higher education in South Africa, they suggest that, while a four-year degree programme would be a progressive move, preparing high school pupils appropriately for higher education remains a challenge (ibidem.).

\section{PARTICIPANTS AND METHODS}

\section{Population sample and profiles}

In order to achieve depth in this study, it focussed on the programmes of one department at the 
University. The population sample were: 100 students of the Department of Tourism Management; 3 content lecturers in the Department of Tourism Management, and 3 English language lecturers from the Department of Applied Languages; the 2 Heads of Department (HoDs) of Tourism Management and Applied Languages, respectively; 3 members of the Advisory Board committees of Tourism Management; and, 3 alumni of this Department. (See Table 1, for a summary of the respondents’ profiles* - only main data presented.)

Table 1: Summary of student respondents' profiles* $(N=109)$

\begin{tabular}{|c|c|c|c|}
\hline \multicolumn{2}{|c|}{ Student respondent group } & \multirow{2}{*}{$\begin{array}{c}\begin{array}{c}\text { Questionnaire } \\
(\mathbf{n}=\mathbf{1 0 0})\end{array} \\
1\end{array}$} & \multirow{2}{*}{$\begin{array}{c}\begin{array}{c}\text { Interview } \\
(n=9)\end{array} \\
1\end{array}$} \\
\hline Race & Asian & & \\
\hline & Black & 91 & 4 \\
\hline & Coloured & 1 & 1 \\
\hline & White & 7 & 3 \\
\hline \multirow[t]{2}{*}{ Sex } & Female & 54 & 4 \\
\hline & Male & 46 & 5 \\
\hline \multirow[t]{2}{*}{ Age ranges } & 18-20 years & 64 & 8 \\
\hline & $21-25$ years & 36 & 1 \\
\hline \multirow[t]{5}{*}{ Home language } & English & 36 & 4 \\
\hline & isiZulu & 16 & 1 \\
\hline & Sepedi & 10 & 1 \\
\hline & Afrikaans & 8 & 3 \\
\hline & seTswana & 6 & - \\
\hline \multirow[t]{2}{*}{$1^{\text {st }}$ Contact with English } & Home & 37 & 4 \\
\hline & School & 63 & 5 \\
\hline
\end{tabular}

It was important to gather information, regarding the wants and needs of all of these stakeholders, since: some of them represented the learners; others, the Management of the University; some were involved in the daily teaching of the students; the alumni provide information, regarding current English offerings; and, the representatives from industry would be able to provide information on industry wants and needs, in relation to students graduating from a UoT.

Since the existing literature dictates that the focus be on the learner, when conducting an EOP needs and wants analysis, it was imperative to gather as much demographic and personal information as possible on the student research participants. Therefore, apart from personal details, such as gender and age, English proficiency level tests of the students were conducted. A section of the questionnaire was also used to allow these students to indicate their use and mastery of languages, to indicate their first encounter with English, and to self-assess their English skills. Without this profiling, an in-depth analysis of EOP wants and needs could not be done. 
Three content lecturers from Tourism Management (2 white males, 40-49 years, $\mathrm{PhD}$ and BTech., Tourism Management; 1 white female, 50-59 years, MTech., Tourism and Hospitality Management) and three English language lecturers, who all taught the Tourism students, were participants. They taught students on all the pathways (i.e., Tourism Management [TM], Event Management [EM], Adventure Tourism Management [ATM]), and had experience of the students’ English proficiency, and feedback from the Work Integrated Learning (WIL) office. This office deployed students from the Department for their practical, experiential learning in industry; this way, they were specifically informed, as to the students' EOP wants and needs.

The three lecturers from Applied Languages (1 black male, 50-59 years, PhD, English; 1 white male, 40-49 years, BA Hons., English; 1 white female, 30-39 years, MTech., Language Practice) had all taught, and were then teaching, English to students of Tourism Management. They were all very familiar with the English proficiency levels of these students, and of their specific language needs.

The Heads of Department (HoDs) of Tourism Management (white female, 50-59 years, PhD, Tourism Management) and Applied Languages (black male, 40-49 years, DLitt et Phil., English) were interviewed, since they represented University Management. In this capacity, they interacted with students, the Management of the University, lecturers, industry representatives, and university alumni. They both had extensive experience, regarding the requesting and rendering of English, as a service subject, to students.

It was decided that input from industry and the Department of Tourism Management's Advisory Boards would be crucial, given the industry-led needs in the students' training at this UoT. Interviews were conducted (one representative per committee), i.e., Tourism Management, Event Management, and Adventure Tourism Management. The Tourism Management representative (white male, 40-49 years, MA, Tourism and Travel Services Management) worked as a Commercial Services and Business Development Manager at the National Zoological Gardens of South Africa, and interacted with local and international tourists regularly. This representative also interviewed students from this UoT for positions at the zoo from time to time. He had vast experience of the tourism industry in South Africa - a career of 24 years in this field, and, therefore, had the requisite knowledge to answer questions, regarding wants and needs for EOP. The Event Management representative (white female, 3039 years, Diploma, Hotel Management, and Certificate, Public Relations) was centrally placed in the Events Management industry as a General Manager in the South African South Association of Conference Management. As such, this interviewee had daily contacts with Events Managers from across South Africa. This interaction provided her with insights into the 
EOP wants and needs of Events Managers. She had approximately 16 years' experience in the Hotel and Conference industry. The representative for Adventure Tourism Management (white male, 60-69 years, Professor of Communication) pioneered white water rafting in South Africa in the 1980s, and owned an Adventure Tourism venture. The interviewee was also a Professor of Communication, and had vast teaching experience over 34 years. This experience, and the hands-on training this candidate supplied to tour guides, made him ideally placed to answer questions, regarding the EOP wants and needs of students of Adventure Tourism Management in South Africa. He was a registered tour guide for the Vredefort Dome and Vaal, and a qualified Assessor.

In addition, to obtain some feedback on their impressions of the English taught at this UoT, establish industry wants and needs, so as to identify gaps in the current curriculum, interviews were conducted with three alumni of the Department of Tourism Management, representing Tourism Management, Adventure Tourism, and Events Management. The alumna of Tourism Management (white female, 50-59 years, MTech., Tourism Management) had comprehensive work experience in the Tourism industry (25 years), and was then a content lecturer in the Department of Tourism Management at this UoT. This experience made her uniquely placed to provide information, regarding the EOP wants and needs of alumni of this UoT. This interviewee was equally familiar with the students' English proficiency at this UoT. The Event Management alumna (white female, 20-29 years, National Diploma, Event Management, Meeting and Event Planning at the UoT) was employed in the Event Management industry as a wedding co-ordinator in the Johannesburg area of South Africa. This interviewee experienced the demands of the Event Management industry on a daily basis, and was, therefore, specifically informed, as to the EOP wants and needs of this industry. The alumnus (white male, 30-39 years, National Diploma, Adventure Tourism Management from the UoT), who was interviewed on Adventure Tourism Management, ran his own Adventure Tourism Management venture in Mmupalanga, South Africa. This venture offered white water tubing/geckoing, caving by candlelight, canyoning/kloofing, abseiling, forest cruises, and team development. His daily running of this business allowed him to specifically identify the EOP wants and needs in Adventure Tourism Management.

\section{Research approach, data collection instruments and procedures}

One hundred (100) questionnaires were administered to participant-students, and semistructured interviews were conducted, i.e., mixed methods (Creswell 1994, 22-23) were used in this exploratory study in the hope of arriving at emergent themes, in terms of wants and needs. 
The student questionnaire sought to gather information on the wants and needs of the students, with regard to developing curricula for EOP in the Department of Tourism Management. Section 1 of the questionnaire elicited personal and demographic information from the students. Section 2 focussed on student wants and needs in English for Tourism. Other student expectations of EOP, and the students' sense of their own language problems, were covered in Section 3. This was a case study, since only one department of the UoT was sampled.

In addition, EOP Oral and Written diagnostic tests were administered on students of Tourism Management, Event Management, and Adventure Tourism Management (seven, each). The students' level of language usage was assessed, in terms of pronunciation (phonetics and phonology), vocabulary, sentence construction, grammar, semantics, and discourse (register and genre), and an average score of 49 per cent was achieved. A holistic assessment of each of the students' oral language proficiency and skills was arrived at. The oral tests also provided an indication of the students' listening and aural comprehension skills. The EOP written diagnostic test was designed specifically to assess their English proficiency, in terms of EOP for Tourism Management. The test entailed questions on discourse and language in the context of tourism. The questions pertained to grammar, syntax, writing in English, spelling, vocabulary, discourse, reading and reading comprehension skills, and punctuation. In this way, the students' language needs were determined, regarding the needs tested. An average score of 39 per cent was achieved. Students received feedback on the diagnostic assessments, to enable them to compare their actual levels of English proficiency to their own perceived levels. This perception of their own English proficiency, was, firstly, determined by a 6-point scale item (Section 1), which asked the students self-assess their English proficiency. Secondly, their own perceptions of their language problems were elicited through an open-ended item (in both the questionnaire and semi-structured interview). The students' responses were then compared with data from the University's Student Development and Support Directorate (SDS), who conduct entrance level tests of students' English proficiency in the Department of Tourism. This testing formed part of their risk-profiling of entry level students at the UoT, and employed the standardised English Literacy Skills Assessment (ELSA) test.

This was followed by semi-structured interviews, conducted with three students from each pathway of specialisation; namely, Tourism Management, Event Management, and Adventure Tourism Management.

The data collection from the other stakeholders in this EOP wants and needs analysis was done after data was collected from the students by means of the semi-structured and focus group interviews. The questions posed sought to determine the wants and needs of stakeholders, the 
face validity they attached to the subject, English, and, the consequences for industry, if students’ English language needs were not met.

All ethical requirements of the institution, at which the study was conducted, were strictly adhered to.

\section{FINDINGS}

For the purpose of analysis, a differentiation was made between wants (i.e., those tasks which learners would wish to perform with language in the occupational environment) and needs (the language skills/knowledge they would need to be able to perform their wants properly).

The following points constitute the main findings of the study, all target groups considered:

1) Since English is crucial to the tourist industry, the majority of respondents felt English should be included in the curriculum at this UoT.

2) Their instructional preference would be a balance between EOP, EAP, and GE, although EOP was regarded as the most relevant. Most students’ weak English proficiency would make it difficult for them to simply learn EOP, which assumes comfortable English proficiency. Some student quotes from the questionnaire illustrate this:

"Some of my lecture cant communicate with me in my language and sometimes I find it difficult to understand English” (EM female student, no. 55).

"Sometimes it is hard for me to understand when the lecture is explaining. And the other problem is Im scared to ask questions sometimes, reason is I cannot speak clearly the language, so I just keep quite even if I dont understand” (ATM female student, no. 84).

3) Most respondents suggested a Foundation programme in English as a possible remedy for the students' sub-standard English proficiency, which constituted a hurdle to passing their content subjects, or EOP.

4) Equally, teaching English over a three-year period could serve to alleviate the problem, and afford students an opportunity to learn EOP while studying.

5) Additionally, attributing a similar number of credits to English (as is assigned to the main content subjects) could serve as an impetus.

6) The service-requesting departments and APL should work more closely together, including in harnessing more authentic teaching materials per pathway for EOP, possibly enhancing the face validity normally attributed by students to English as a subject.

7) Each service-requesting department should be able to conduct their own EOP needs 
analysis, so as to reinforce the quality of training per pathway.

8) Valuable inputs, regarding EOP curriculum development, could emanate from the Department of Tourism Management’s Work-Integrated Learning (WIL) Office, as well as the Advisory Board of the DTM.

9) The highest means on wants were associated with job application, conflict resolution, and negotiation skills. Letter writing, memo writing, and article writing recorded the lowest means (see Table 2).

Table 2: Students' Wants List Likert Scale Ratings $(\mathrm{N}=100)$

\begin{tabular}{|l|c|}
\hline Wants List & Means \\
\hline Job applications & 4.0 \\
\hline Conflict resolution skills & 4.0 \\
\hline Negotiation skills & 3.9 \\
\hline Documents for meetings & 3.8 \\
\hline Assignment writing & 3.8 \\
\hline Report writing & 3.7 \\
\hline Article writing & 3.6 \\
\hline Memo writing & 3.5 \\
\hline Letter writing & 3.4 \\
\hline
\end{tabular}

Key: 1: "Not wanted at all"; 2: "Not wanted"; 3: "Wanted"; 4: "Important"; 5: "Essential"

10) Sentence construction, oral presentation, and pronunciation were listed as the skills the students most needed to learn, whereas reading and aural comprehension skills were indicated as those skills they thought they least needed to learn. This may be an indication that they were unaware of their own weak English proficiency (see Table 3).

Table 3: Students' Needs List Likert Scale Ratings $(N=100)$

\begin{tabular}{|l|c|}
\hline Needs List & Means \\
\hline Sentence construction & 3.9 \\
\hline Oral presentation skills & 3.8 \\
\hline Pronunciation & 3.8 \\
\hline Vocabulary & 3.8 \\
\hline Spelling & 3.8 \\
\hline Grammar & 3.7 \\
\hline Punctuation & 3.7 \\
\hline Listening comprehension skills & 3.7 \\
\hline Reading comprehension skills & 3.6 \\
\hline
\end{tabular}

Key: 1: "Not wanted at all"; 2: "Not wanted"; 3: "Wanted"; 4: "Important"; 5: "Essential" 


\section{DISCUSSION, CONCLUSIONS, AND RECOMMENDATIONS}

\section{English proficiency as a pre-requisite for the learning and teaching of EOP}

West (1994, 9-10) recommends that there should be a process for establishing a learner profile, when developing a curriculum or syllabus specific to a certain target group. Therefore, the student profiling that was done was essential.

It became evident from the data gathered by means of the EOP wants and needs analysis in this research that students' sub-standard English proficiency should be addressed, before EOP could be taught successfully.

It was also clear from the data on the students' profiling by means of the EOP diagnostic and ELSA tests, that students' levels of English proficiency were so low that this would hamper their performances in their studies, in general, and prevent them from functioning efficiently and appropriately in an occupational environment. It was evident from the profiling section of the questionnaire that many students were unaware that their levels of English proficiency were rather low.

Fatihi $(2003,41)$ remarks that the most important problem of language learners, mainly in developing countries, is that, although they supposedly learn English over extended periods, their English proficiency remains sub-standard.

According to the British Council $(2012,1)$, the fact that learners have good proficiency in General English at a younger age means that they can learn ESP/EOP at a younger age. This is not the case in South Africa, a developing country, where learners' academic literacy and English proficiency at this UoT is generally sub-standard.

\section{Stakeholders' input on how to address students' poor English proficiency}

The fact that all stakeholders, besides the students, indicated that students would, firstly, not be employed, and, secondly, would struggle to cope in the occupational world, if they were employed, should their language needs not be met, is a clear indicator that poor English proficiency must be addressed urgently. If these needs were met, the process of quality assurance to prospective employers could already be initiated.

Edwards (2000) believes that, if both students and the employer are satisfied with the EOP course aims and objectives, there would be motivation to study, and students would be prepared to immediately apply their knowledge, and perform more effectively in the occupational world.

Findings from the semi-structured and focus group interviews indicated that students who did not have the appropriate levels of English proficiency should be directed onto a Foundation 
programme. This would mean that the current admission requirements for students to enrol at the UoT should be reviewed, so as to assign the students into streams, based on their levels of English proficiency. Students, who had the required levels of proficiency, could be allowed straight into the academic mainstream at first year level, and immediately be allowed to study EOP. Carver (1983) agrees that admission requirements to ESP should be set, because students with low levels of English proficiency simply cannot master content activities.

Alternatives to a Foundation programme, as suggested by stakeholders, to alleviate substandard English proficiency, could be that students study English over all the three years of their degree programme, or, at least, over the first two years. The first year could be dedicated to improving English proficiency. EOP could then be studied in the second year, when their English proficiency levels may have improved. Popescu (2012, 4185) is of the view that ESP courses are integral at technical universities, and that ESP, specifically, should be a compulsory subject for a minimum of two years.

\section{Face validity students attach to the English subject}

The lack of insight into their own poor English proficiency, and the very real language needs that students displayed, could also explain the poor face validity that students attached to the subject, English, and their lack of understanding of how it fits into their pathways, and how it could benefit them in their academic achievement in other subjects, and, eventually, in the occupational world.

The face validity students attribute to English is considered an important factor to consider in a needs analysis (Dudley-Evans and St John 1998, 125). Therefore, the face validity that students attach to the subject, English, could be addressed by means of acknowledging their wants and needs, and through collaboration between content lecturers and English language lecturers.

There were students who indicated that they had specific English language needs, and that they were aware that these could hamper their academic achievement, and interaction with clients in the occupational environment. Ngoepe $(2012,61)$ points out that ESP/EOP materials require good language proficiency in GE, since English, aimed at field-specific areas, is addressed.

\section{EOP vs. EAP and GE}

Students indicated that they would prefer to study mainly EOP. This was supported by the other stakeholders, who indicated that they would prefer the focus to be on EOP, and not GE, since this was a UoT, and the institution should produce students who were ready to function in the professional world upon graduation. However, lecturers felt that, if students' English 
proficiency was not yet in place, EAP could be included to help alleviate this problem.

Dovey $(2006,388)$ mentions that courses are now developed specifically for contemporary students to function in their chosen professions. She adds that, for the majority of students, EAP cannot prepare them to do this. EAP would, at most, prepare postgraduate research students to function well.

Most of the respondents also indicated that, ideally, English should carry the same credits as the main content subjects. The shared opinion of all stakeholders was that students would not be able to function in the occupational world without English, which was seen as the corporate language.

According to Sujana $(2102,1)$, students at most universities in Indonesia have very low levels of English proficiency, partially because a limited number of credits are allocated to English. The same might be true at this institution, and, therefore, it would be imperative to consider increasing the credits for English as a subject.

Benesch (1996, 726) highlights the fact that the political climate in an academic institution, and a country, could influence how change is effected in the learning of EOP. Stakeholders referred to the fact that the Management of the University should make more funding available to improve the poor English proficiency of students by allocating more credits to English as a subject. The allocation of more credits would also mean allocation of funds for the appointment of more human resources, and, have an impact on curriculation practices at the institution.

\section{Collaboration among lecturers, and using authentic teaching and learning materials}

There was consensus among the stakeholders that close co-operation should be nurtured between the departments requiring language services and the Department of Applied Languages, and could culminate in the provision of more authentic EOP teaching materials per pathway.

The collaboration could incorporate both assessments for content subjects, and for English. It would involve field-specific materials to be provided by content lecturers, and the English language component to be provided by the English language lecturers. Such collaboration could also enhance the face validity students attribute to English as a subject. Portfolios, as assessment tools, were suggested as a means to make this collaboration practical.

Ngoepe $(2012,60)$ is of the opinion that field-specific ESP learning materials should meet language needs through collaboration among lecturers. Esteban and Vallejos Martos (2002, 1011) agree, when they state that the content teacher could provide the topic, and the language teachers could provide the linguistic content. Ngoepe, Esteban, Vallejos, and Martos, therefore, 
support the consensus among stakeholders in this study, regarding collaboration, and the use of authentic teaching materials.

Gatehouse (2001, 7) concurs that content teachers should be approached for input when an ESP (EOP) curriculum is developed, since curriculum development cannot be done without this input. However, Ahmadi and Bajelani $(2012,792)$ are of the opinion that many students are not prepared to study ESP/EOP, and most authentic texts are too difficult for them to understand. This should be taken into consideration, if students' poor English proficiency is improved before they are allowed to study EOP.

\section{The role of the Advisory Board in EOP curriculum development}

Department of Tourism Management lecturers interviewed were not of the view that the Advisory Board added value to the curriculum development process, whereas most of the other stakeholders believed the Advisory Board had a role to play. For the DTM lecturers, the WorkIntegrated-Learning (WIL) Office was in a better position to offer more practical input, since they had direct experiences of the students’ performances in industry.

Swales had stated that corporate culture is a very important variable in EOP - a variable that could be provided by the Advisory Board (interview with Pérez-Llantada 2004, 140). We have already alluded to Nunan's $(1987,75)$ position those serving in a curriculum advisory role constitute relevant support.

\section{EOP wants and needs}

Since there was agreement, as well as differences of opinion, among stakeholders, and per pathway, pertaining to the wants and needs that emerged from this study, it would be imperative to conduct a wants and needs analysis per pathway. Hutchinson and Waters $(1987,55-56)$ had suggested that learners' wants could be the direct opposite of what other stakeholders determine as imperative as learning materials.

Diversification, in terms of wants and needs per pathway, and per department, should be incorporated in the development of curricula for EOP at a UoT. This way, authenticity could be ensured, in terms of learning and teaching materials per pathway. It would also increase the face validity that students attach to the subject, "English/Communication skills".

\section{Designing an EOP curriculum at a UoT}

Aside from all the data that emerged from this study, which support existing literature on EOP and curriculum development, it is noteworthy that data emerged supporting direct feedback from companies hosting students for their industry training. This could be explored by means of a tool developed to elicit such information, regarding EOP wants and needs in industry, e.g., a model questionnaire to be circulated to companies. 


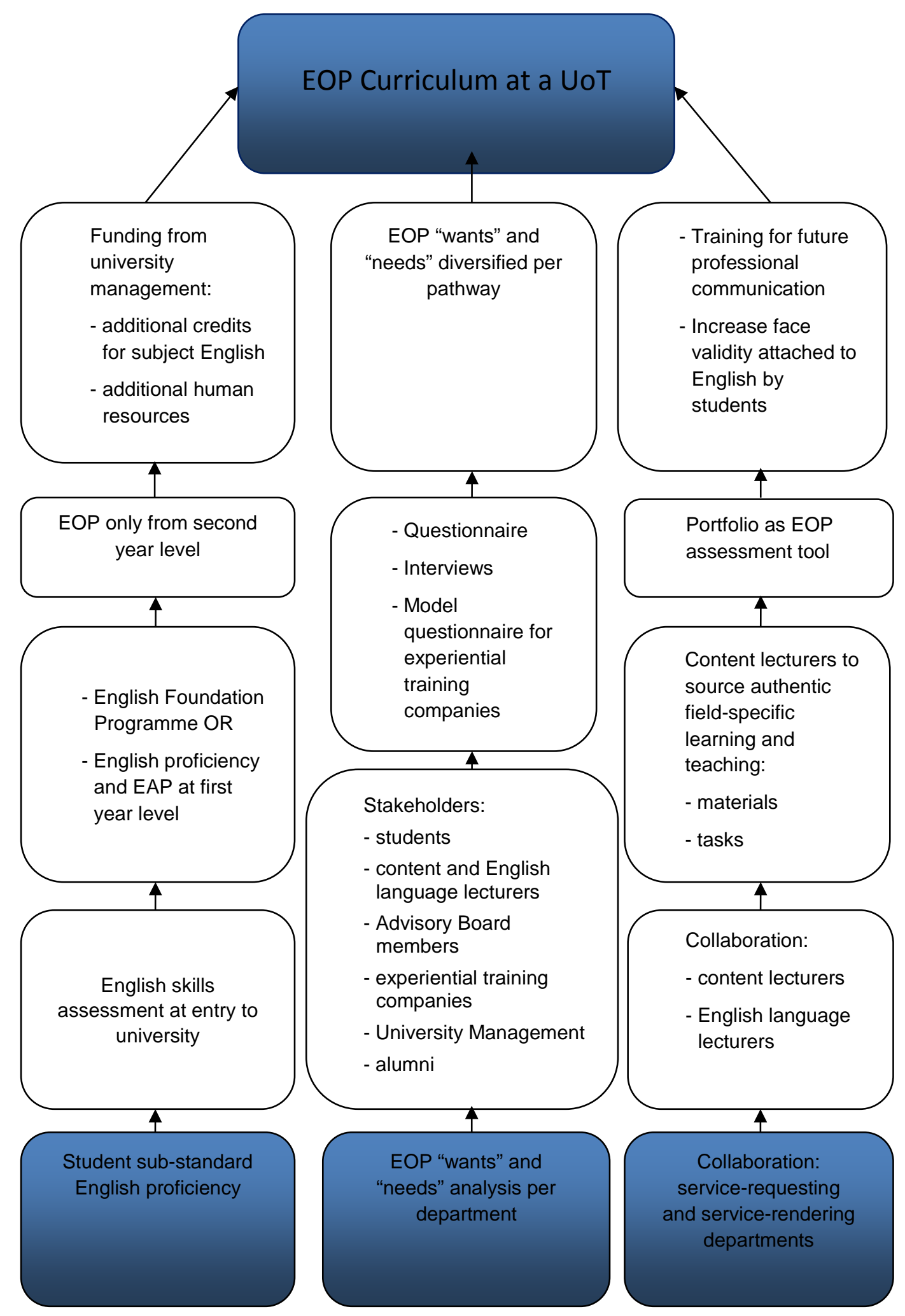

Figure 1: Principles and procedures for EOP curriculum design at a UoT

Figure 1 illustrates the principles and procedures for the design of an EOP curriculum at a UoT, based on the findings in this study. 


\section{REFERENCES}

Ahmadi, A. and M. R. Bajelnai. 2012. Barriers to English for specific purposes learning among Iranian university students. Procedia - Social and Behavioral Sciences 47: 792-796. http://www.sciencedirect.com (Accessed 27 August 2012)

Belcher, D. 2004. Trends in teaching English for specific purposes. Annual Review of Applied Linguistics 24: 165-186.

Benesch, S. 1996. Needs analysis and curriculum development in EAP: An example of a critical approach. TESOL Quarterly 30(4): 723-738. http://www.jstor.org/stable/3587931 (Accessed 5 March 2012).

British Council. 2012. English for specific purposes: Introduction. http://www.teachingenglish.org.uk/ transform/teachers/specialist-areas/english-specific-purposes.htm (Accessed 20 February 2012).

Brunton, M. 2009. An account of ESP - with possible future directions. English for Specific Purposes 8(3): 1-15. http://www.esp-world.info (Accessed 20 February 2012).

Carver, D. 1983. Some propositions about ESP. The ESP Journal 2: 131-137. http://www.tuchemnitz.de/phil/english/te/ESP-EAP.pdf (10 January 2012).

Creswell, J. W. 1994. Research design: Qualitative, quantitative and mixed methods approaches. $2^{\text {nd }}$ Edition. http://www.jstor.org/stable/2392366 (Accessed 4 October 2013).

Diaz, C. A. 2011. EOP vocabulary to improve communication between Tourism professionals and international tourists visiting Nayarit. Memorias de las jornadas de lenguas en contacto, May: 1-8 http://www.cucsh.uan.edu.mx/jornadas/modulos/memoria/alcantar_eop_vocabulary.pdf (Accessed 25 November 2014).

Dovey, T. 2006. What purposes specifically? Rethinking purposes and specifically in the context of the "new vocationalism". English for Specific Purposes 25: 387-402. http://www.sciencedirect.com/ science/article/pii/S0889490605000670 (Accessed 25 November 2014).

Dudley-Evans, T. and M. St John. 1998. Developments in ESP: A multi-disciplinary approach. Cambridge: Cambridge University Press.

Edwards, N. 2000. Language for business: Effective needs assessment, syllabus design and materials preparation in a practical ESP case study. English for Specific Purposes 19(3): 291-296. http//www.sciencedirect.com/science/article/pii/S0889490698000295 (Accessed 5 March 2012).

Esimaje, A. U. 2012. A corpus-based lexical study of sermons in Nigeria. English Language Teaching 5(9): 24-32. http://dx.doi.org/10.5539/elt.v5n9p24 (Accessed 28 August 2012).

Esteban, A. A. and M. C. Vallejos Martos. 2002. A case study of collaboration among the ESP practitioner, the content teacher, and the students. Revista Alicantina de Estudios Ingleses15(7): 7-21. http://rua.ua.es/dspace/bitstream/10045/5250/1/RAE_15_01.pdf (Accessed 8 December 2011).

Fatihi, A. R. 2003. The role of needs analysis in ESL program design. South Asian Language Review XIII, 1\&2, January-June: 39-59. http://www.geocities.ws/southasianlanguagereview/ SecondLanguage/fatihi.pdf (Accessed 25 November 2014).

Gatehouse, K. 2001. Key issues in English for Specific Purposes (ESP) curriculum development. The Internet TESL Journal vii (10). http://iteslj.org/Articles/Gatehouse-ESP.html (Accessed 8 December 2011).

Hutchinson, T. and A. Waters. 1987. English for special purposes: A learning-centred approach. Cambridge: Cambridge University Press.

Kennedy, C. 2012. ESP projects, English as a global language, and the challenge of change. Ibérica 24: 43-54. http://www.aelfe.org/documents/05-24-Kennedy.pdf (Accessed 16 October 2012).

Kim, D. 2008. English for occupational purposes. London: Continuum.

Le Ha, P. 2005. Munby’s “needs analysis” model and ESP. Asian EFL Journal 6: 1-8. http://asian-efljournal.com/pta_october_07_plh.php (Accessed 5 March 2012). 
Ngoepe, L. J. 2012. To what extent do science ESP materials fit the purpose for which they have been devised? An evaluation in terms of Cronje's (1993) criteria. Journal for Language Teaching 46(1): 60-73.

Nunan, D. 1987. The teacher as curriculum developer: An investigation of curriculum processes within the adult migration education program. South Australia: National Curriculum Resource Centre.

Pérez-Llantada, C. 2004. An interview with John M. Swales: An overview of genre analytical studies in English for Academic Purposes. IBÉRICA 8: 139-148. http://www.aelfe.org/documents/09Interv-8-PL/antadaPDF (Accessed 23 March 2012).

Popescu, A-V. 2012. Teaching ESP $1^{\text {st }}$ year students of electronics and telecommunications. Procedia - Social and Behaviourial Sciences 46: 4181-4185. http://www.sciencedirect.com (Accessed 10 September 2012).

Prince, R. and N. Yeld. 2012. A bridge too far for school leavers. Mail \& Guardian Oct. 12. http://www.mg.co.za/article/2012-10-12-a-bridge-too-far-school-leavers (Accessed 13 November 2012).

Rajaee Nia, M., E. Abbaspour and J. Zare. 2012. A critical review of recent trends in second language syllabus design and curriculum development. International Journal of Research Studies in Language Learning: 1-20. http://www.consortiaacademia.org/index.php/ijrsll/article/viewFile/ 152/133 (Accessed 21 August 2012).

Salmani-Nodoushan, M. A. 2002. Text familiarity, reading tasks, and ESP test performance: A study on Iranian LEP and non-LEP university students. Language in India 6(1): 1-236. http://www.languageinindia.com/jan2006/DissertationPHD.pdf (4 December 2014).

Sifakis, N. C. 2003. Applying the adult education framework to ESP curriculum development: An integrative model. English for Specific Purposes 22: 195-211. http://www.sciencedirect.com (accessed 5 March 2012).

Songhori, M. H. 2008. Instruction to needs analysis. English for Specific Purposes 4: 2-25. http://www.esp-world.info (Accessed 6 March 2012).

Smythe, M-J. and L. A. Nikolai. 2002. A thematic analysis of oral communication concerns with implications for curriculum design. Journal of Accounting Education 20: 163-181. http://www.elserivier.com/locate/jaccedu (Accessed 20 February 2012).

Sujana, I. M. 2012. Integrating a mind mapping technique and information gap activities in teaching academic reading in English. English for Specific Purposes World 36(12): 1-19. http://www.espworld.info (Accessed 8 October 2012).

Swales, J. M. 1990. Genre analysis: English in academic and research settings. Cambridge: University Press.

West, R. 1994. Needs analysis in language teaching. Language Teaching 27:1-19. 